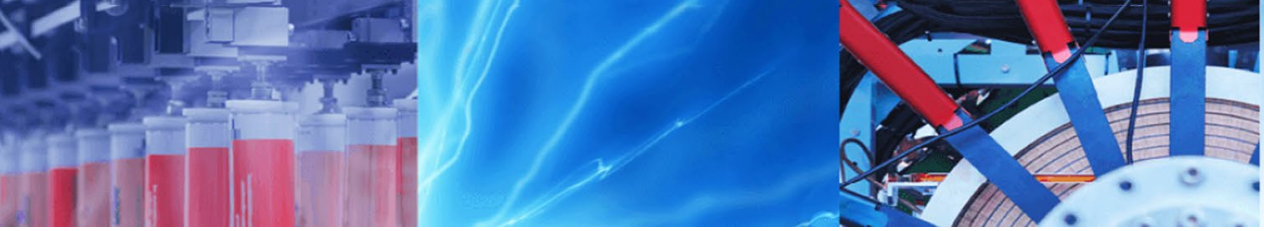

Research Article

\title{
Biosorption of copper(II) and cadmium(II) by Bacillus cereus sys 1 isolated from oil-contaminated site
}

\author{
Sheetal Sonawdekar ${ }^{1} \cdot$ Arpita Gupte $^{1}[$
}

Received: 5 January 2020 / Accepted: 12 June 2020 / Published online: 20 June 2020

(c) Springer Nature Switzerland AG 2020

\begin{abstract}
Biosorption of copper(II) and cadmium(II) was studied using Bacillus cereus sys 1 cells. The biosorption capacity of the cells has been studied as a function of $\mathrm{pH}$, initial metal concentration, cell concentration and contact time. Batch studies showed that the B. cereus sys 1 cells could adsorb up to $90 \%$ of both metals. For copper, total contact time of 90 min was required with $100 \mathrm{ppm}$ initial metal concentration at pH 5 using $10 \mathrm{mg} / \mathrm{ml}$ cells, whereas $180 \mathrm{~min}$ was required for 30 $\mathrm{ppm}$ cadmium at $\mathrm{pH}$ 7. The study demonstrated correlation with Langmuir model with different concentrations of both $\mathrm{Cu}(\mathrm{II})$ and $\mathrm{Cd}(\mathrm{II})$. The adsorption capacity was found to be $225 \mathrm{mg} / \mathrm{g}$ for copper and $34.67 \mathrm{mg} / \mathrm{g}$ for cadmium. As per the Freundlich isotherm, value of $1 / n$, which shows the strength of adsorption, was found to be 0.5114 for copper and 0.2492 for cadmium indicating a normal and favourable adsorption intensity. The surface adsorption of metals was confirmed using SEM with EDS. It revealed that the cells treated with oil could adsorb $7.55 \%$ copper as compared to untreated cells which showed $7.29 \%$ adsorption. Similarly, for cadmium oil-treated cells showed $9.44 \%$ adsorption compared to $2.63 \%$ of untreated cells. This indicated that the cells grown in the presence of oil have a better capacity for metal ion adsorption.
\end{abstract}

Keywords Heavy metal bioremediation $\cdot$ AAS $\cdot$ SEM with EDS $\cdot \mathrm{Cu}(\mathrm{II}) \cdot \mathrm{Cd}(\mathrm{II})$

\section{Introduction}

Metal pollution is one of the major concerns of the current era [1, 2]. In recent years, mushrooming of several industries has intensified the problem of metal pollution [3]. There are several heavy metals that enter into the environment through different sources. Copper(II) and cadmium(II) are two of such metal contaminants [4]. Copper enters into the environment through natural and anthropogenic sources. The contamination of air and water by copper occurs due to mining, milling, concentrating, refining of copper ores, electroplating industries, petroleum and reefing melting plants and miscellaneous units from industries, whereas cadmium can be released to the atmosphere through metal production activities, fossil fuel combustion and waste incineration [5]. The presence of copper(II) ions causes serious toxicological concerns. It is usually known to deposit in brain, skin, liver, pancreas and myocardium $[1,6]$. In high doses, it can cause anaemia, liver and kidney damage and sometimes stomach and intestinal irritation [7]. Cadmium is an extremely toxic metal commonly found in industrial workplaces. Cadmium is extensively used in electroplating, although the nature of the operation does not generally lead to over exposures. As per the different studies done over the years, only a small proportion (5-10\%) of ingested cadmium is absorbed by humans [8,9]. Cadmium is capable of causing severe renal dysfunction and damage to the bone structure $[1,10]$. Currently, common methods in use for metal removal are physical, chemical or mechanical in nature [11]. Due to incomplete decomposition of pollutants and high cost of operation, there is a need for the better

Arpita Gupte, garpita@gmail.com | 'School of Biotechnology and Bioinformatics, DY Patil deemed to be University, Navi Mumbai, Maharashtra, India. 
methods of pollution control. In view of this, biosorption is becoming an increasingly popular technique for cleaning up the metal-contaminated sites. Biosorption, which is the ability of certain microbial biomaterials to bind and concentrate heavy metals from even the most dilute aqueous solutions, offers a technically feasible alternative [12]. Algae, bacteria, fungi and yeasts have proved to be potential metal biosorbents [13]. It is considered an ideal alternative method for removing contaminants from effluents as well.

The Bacillus cereus sys 1 cells used in this study were isolated from oil-contaminated sites. They were found to be exopolysaccharide producers and exhibited oil degrading potential [14]. The present work delineates the use of $B$. cereus sys 1 cells as a potential biosorbent for copper(II) and cadmium(II) metal ion removal.

\section{Materials and methods}

\subsection{Growth of Bacillus cereus sys 1}

The $B$. cereus sys 1 cells were isolated from oil-contaminated soil in and around Thane District, Maharashtra, India. These cells were grown in sterile nutrient broth as described by Gupte and Sonawdekar [14]. All the studies during the present work were carried out using freshly harvested cells. Unless otherwise stated, the amount of cells used in these studies has been indicated in terms of wet weight of the packed cells obtained after centrifugation.

\subsection{Preparation of metal solution}

Stock solutions of $\mathrm{Cu}$ (II) (2000 ppm) and $\mathrm{Cd}$ (II) (100 ppm) were prepared using copper sulphate $\left(\mathrm{CuSO}_{4} \cdot 5 \mathrm{H}_{2} \mathrm{O}\right)$ and cadmium nitrate $\left[\mathrm{Cd}\left(\mathrm{NO}_{3}\right)_{2} \cdot 4 \mathrm{H}_{2} \mathrm{O}\right]$ in deionized water, respectively. The required concentrations of both the metal ions were prepared by appropriate dilution of corresponding metal stock solutions.

\subsection{Uptake studies}

Biosorption studies were carried out in a batch process. For this study, B. cereus sys 1 cells $(10 \mathrm{mg} / \mathrm{ml})$ were inoculated in $50 \mathrm{ml}$ of an aqueous solution of copper (100 ppm) and cadmium (30 ppm) separately. The $\mathrm{pH}$ was adjusted to 5 for $\mathrm{Cu}(\mathrm{II})$ and to 7 for $\mathrm{Cd}(\mathrm{II})$ metal solution. The adsorption studies were carried out at constant temperature (room temperature $\left(30 \pm 2{ }^{\circ} \mathrm{C}\right)$ [15]. Aliquots taken at a known interval of time were centrifuged at $8000 \mathrm{rpm}$ for $5 \mathrm{~min}$ to remove cells, and the supernatant was used for the determination of residual metal concentration at $327.4 \mathrm{~nm}$ for copper and $228.8 \mathrm{~nm}$ for cadmium using atomic absorption spectroscopy (AAS) [15-20].

\subsection{Effect of different pre-treatments on metal uptake}

Different pre-treatments to remove exopolysaccharide from the cells were carried out as: (a) oven drying for 20 h at $60^{\circ} \mathrm{C}$, (b) autoclaving at $15 \mathrm{lbs}$, (c) $121^{\circ} \mathrm{C}$ for $20 \mathrm{~min}$, (d) incubating in a boiling water bath for $60 \mathrm{~min}$ and (e) acetone drying [18].

\subsection{Characterization of biomass}

The surface characteristics of $B$. cereus sys 1 cells were analysed before and after metal biosorption using scanning electron microscope (SEM) with energy-dispersive X-ray spectroscopy (EDAX).

\section{Results and discussion}

\subsection{Effect of cell concentration}

The cell concentration influences metal uptake capacities. To study the effect of cell concentration on biosorption of copper and cadmium, the biomass of varying concentrations $(1-30 \mathrm{mg} / \mathrm{ml}$ ) was incubated with aqueous solution of respective metals for $24 \mathrm{~h}$ and sorption studies were carried out as described earlier. Figure 1 shows the effect of cell concentration on biosorption of $\mathrm{Cu}(\mathrm{II})$ and $\mathrm{Cd}(\mathrm{II})$. Copper biosorption was found to be maximum (73\%) with cell concentration of $10 \mathrm{mg} / \mathrm{ml}$. In the case of cadmium, 10 $\mathrm{mg} / \mathrm{ml}$ and $30 \mathrm{mg} / \mathrm{ml}$ cells showed $86 \%$ and $88 \%$ sorption, respectively. This can be due to the increase in the number of binding sites at higher cell/biosorbent concentrations. At very low cell concentration, the cell surface becomes saturated with the metal ions and the large amounts of metal ions remain in the solution [19]. During the study, it was observed that $\mathrm{Cu}$ (II) uptake was found to be reduced with $30 \mathrm{mg} / \mathrm{ml}$ cells. At very high cell concentration, the competition between the binding sites increases which might have led to desorption of copper ions. This can also be attributed to availability of solute, electrostatic interactions, interference between binding sites and reduced mixing at high biomass densities [20].

\subsection{Effect of $\mathrm{pH}$}

$\mathrm{pH}$ plays an important role in metal uptake. To study the effect of $\mathrm{pH}$ on biosorption of copper and cadmium, the biomass of varying concentrations $(1-30 \mathrm{mg} / \mathrm{ml})$ was incubated with aqueous solution of respective metals for 
Fig. 1 Effect of cell concentration on biosorption using 100 ppm copper at $\mathrm{pH} 5$ and 30 ppm cadmium at $\mathrm{pH} 7$

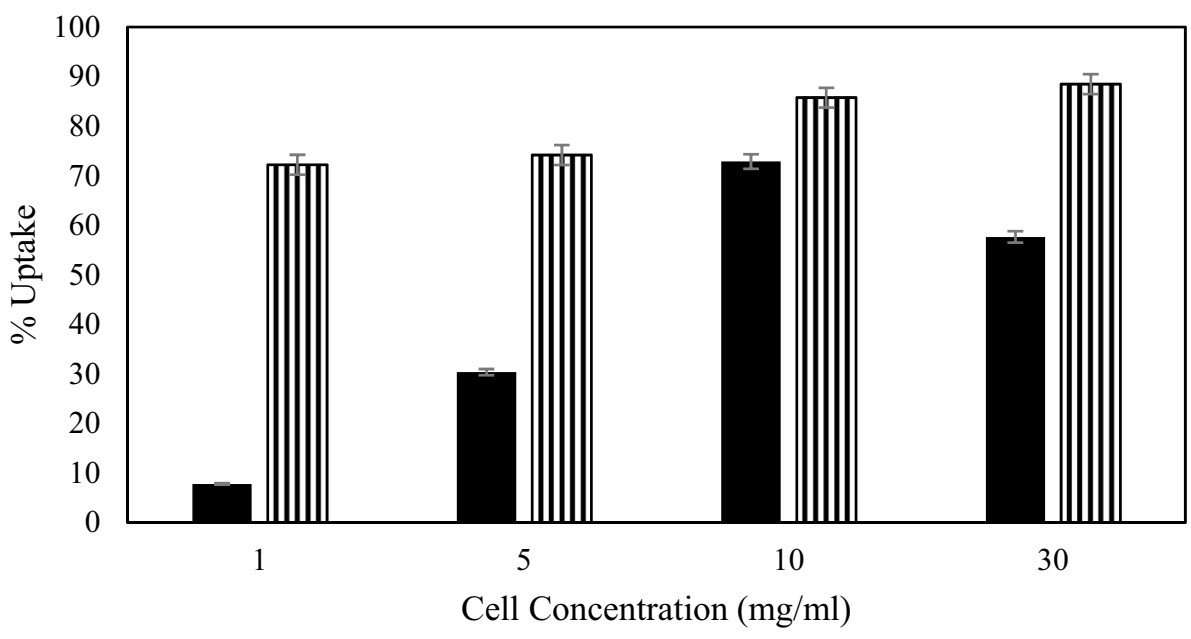

- \% Uptake for $\mathrm{Cu}$ 四\% uptake for $\mathrm{Cd}$
$24 \mathrm{~h}$ and sorption studies were carried out as described earlier. Due to precipitation of copper beyond $\mathrm{pH} 5$, the study of effect of $\mathrm{pH}$ on copper sorption was conducted only till $\mathrm{pH} 5$. Figure 2 shows the effect of $\mathrm{pH}$ on biosorption. Copper biosorption was found to be $73 \%$ at $\mathrm{pH} 5$, whereas for cadmium it was found to be $88 \%$ at $\mathrm{pH} 7$ with cell concentration of $10 \mathrm{mg} / \mathrm{ml}$. It was seen that the cadmium sorption was not dependent on $\mathrm{pH}$ as no change in metal sorption was observed at different $\mathrm{pH}$, whereas copper sorption was found to increase with increasing $\mathrm{pH}$. At lower $\mathrm{pH}(<6)$, concentration of proton is high, so metal binding sites become positively charged. Metal cations and protons compete for binding sites which results in lower metal uptake [21]. The studies conducted by Gupte and Nair [17] demonstrated that the removal efficiency of $\mathrm{Cu}(\mathrm{II})$ increases from the $\mathrm{pH} 3$ to 5 with slight increase after $\mathrm{pH}$ 5. These results also suggest that ionic interaction is the main mechanism contributing to biosorption of metals. At low $\mathrm{pH}$, hydrogen ions compete with metal ions, resulting in protonation of active sites. But as the $\mathrm{pH}$ increases, the negative charge density on the surface of adsorbent increases and the ionic point of ligands such as carboxyl, hydroxyl and amino groups is free so as to promote interaction with the metal cations [17]. Increased sorption with increasing $\mathrm{pH}$ can also be attributed to lower degree of hydration of hydrolysed species as it requires less energy for removal or reorientation of the hydrated water molecules upon binding.

\subsection{Effect of metal ion concentration}

The metal ion concentration can influence metal uptake capacity of the cells. To study the effect of copper and cadmium concentration on biosorption, $50-250 \mathrm{ppm}$ and 10-50 ppm were used, respectively, and sorption studies were carried out as described earlier. Copper sorption
Fig. 2 Effect of pH on biosorption of $100 \mathrm{ppm}$ copper and 30 ppm cadmium using $10 \mathrm{mg} / \mathrm{ml}$ cell concentration

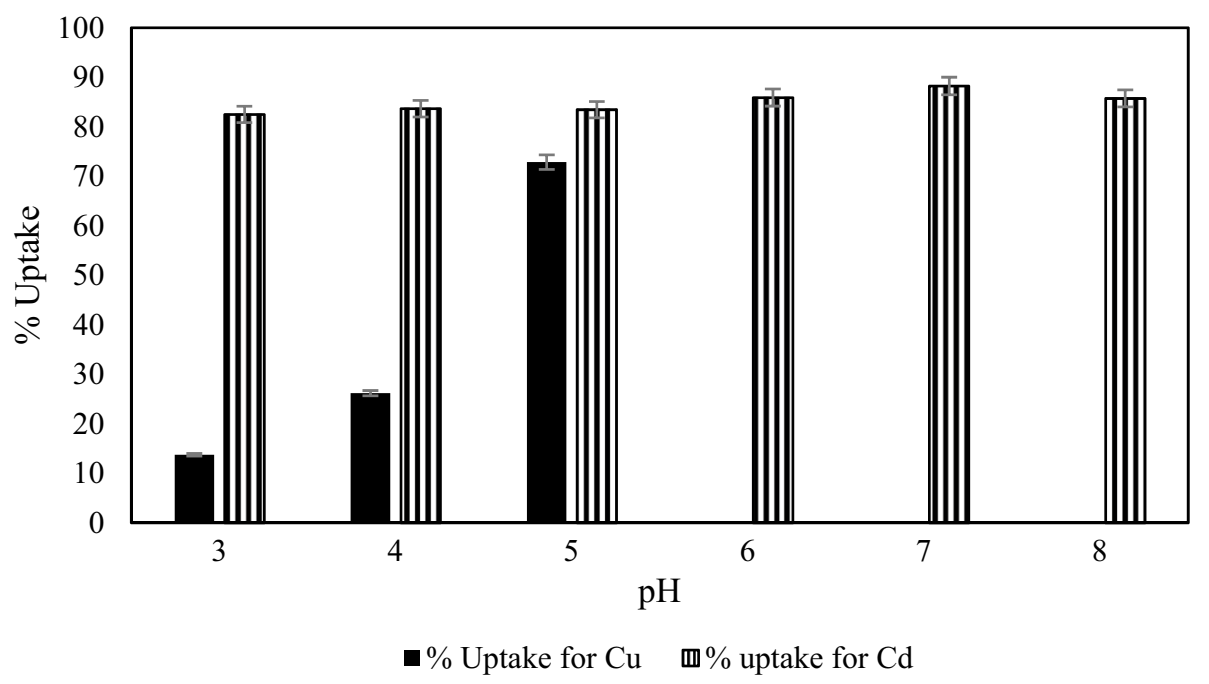

SN Applied Sciences 
was found to be maximum (73\%) for 100 ppm as shown in Fig. 3a. The sorption efficiency for copper was found to decrease with increase in the metal concentration. Figure $3 \mathrm{~b}$ represents the effect of cadmium concentration. The maximum uptake (90\%) was found to be at $20 \mathrm{ppm}$ cadmium concentration. The efficiency of the cells to uptake cadmium was found to decrease at higher concentrations. It suggests that the biosorption is highly dependent on initial concentration of metal ion and at very high concentration of metal ions it reaches a saturation value [19].

This indicates that at higher metal concentrations, the available sites for adsorption become fewer and biosorbent sites take up the available metal more quickly at lower metal concentrations. The similar findings were reported by Khadivinia et al. [22] while studying cadmium sorption in Ochrobactrum spp.

\subsection{Effect of different pre-treatments}

The $B$. cereus sys 1 cells used in the study were isolated from oil-contaminated sites and had exopolysaccharide (EPS) layer on the surface and were found to be capsular exopolysaccharides containing carboxyl group [14]. Different pre-treatments were used for removal of EPS, and the

(a)

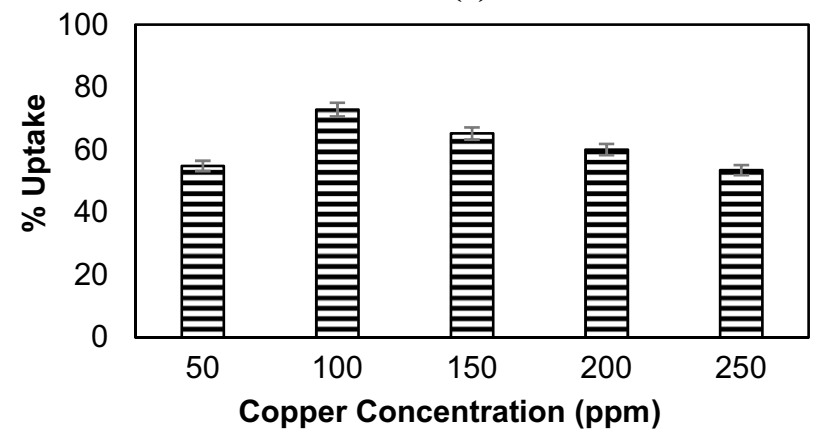

(b)

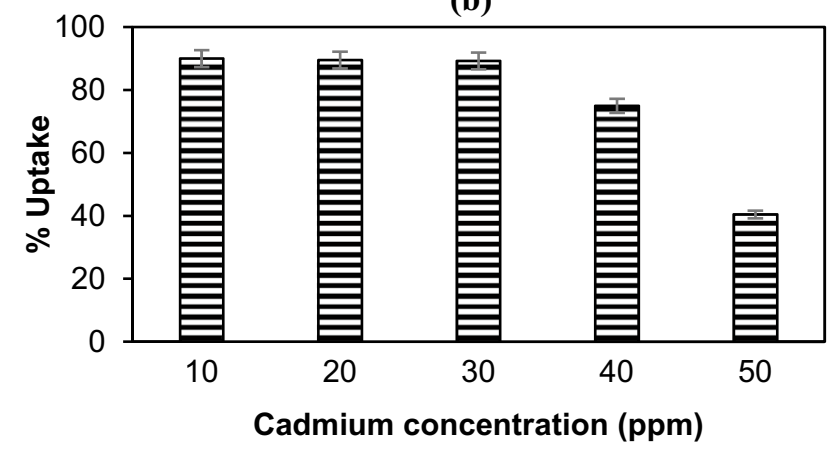

Fig. 3 Effect of a copper dosage on biosorption of copper at $\mathrm{pH} 5$, b cadmium dosage on biosorption of cadmium at $\mathrm{pH} 7$ using 10 $\mathrm{mg} /$ cell concentration effect was studied on metal sorption. The untreated cells showed maximum metal adsorption for copper as well as cadmium (Fig. 4).

The similar study conducted by González et al. [18] using Pseudomonas aureofaciens showed that EPS-rich cells have better metal adsorption capacity than the EPSpoor cells. It was also observed that the pre-treatment of cells affected the copper sorption but did not have much effect on cadmium sorption. Similar pre-treatments were used in the metal uptake studies for Aspergillus niger [23].

\subsection{Time kinetics}

The kinetic studies were carried out to determine the rate of metal sorption by $B$. cereus sys 1 cells. Rapid removal of both the metal ions was seen within first $5 \mathrm{~min}$ as shown in Fig. 5. After the initial rapid uptake, it continued with slow rate until the equilibrium was attained. Equilibrium for Cu uptake was achieved at $90 \mathrm{~min}$, whereas for $\mathrm{Cd}$ it was achieved at $180 \mathrm{~min}$.

Initial higher rate of metal uptake may be attributed to the initial high metal concentration and availability of a large number of active sites on adsorbent [24]. Similar

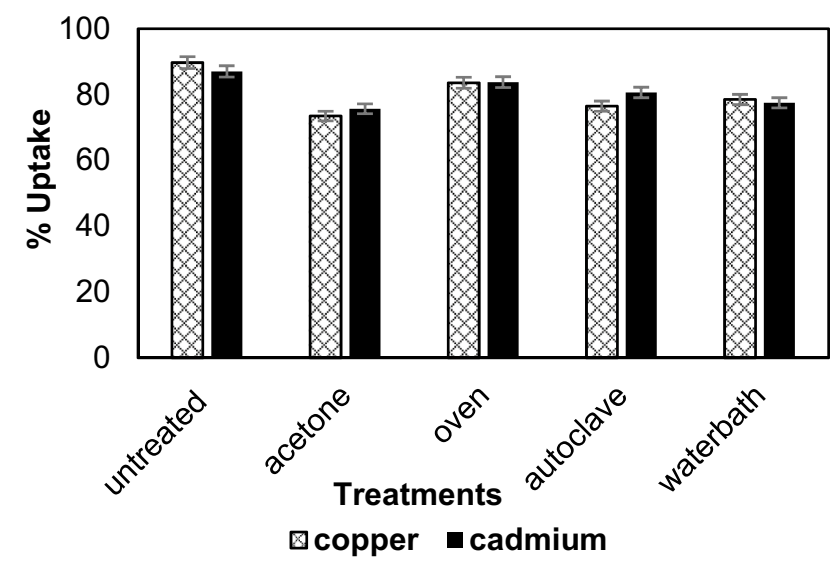

Fig. 4 Effect of different pre-treatments on copper and cadmium uptake at $2 \mathrm{~h}$

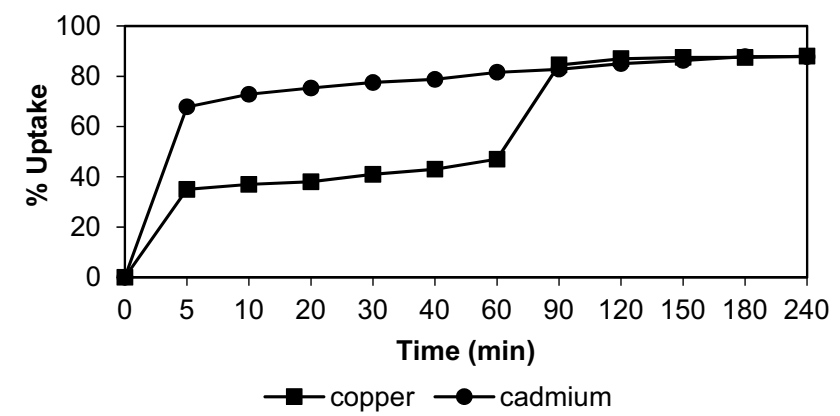

Fig. 5 Time kinetics for normal cells using copper and cadmium 
trend was observed in study conducted by Rajendran et al. [25] and showed that copper-resistant B. cereus spp. isolated from industrially polluted areas could adsorb copper in the range of $84 \%$ within $24 \mathrm{~h}$. Several other studies carried out for copper adsorption [20,26, 27] also reported maximum uptake within 4-24 h. Kulkarni et al. [28] studied the cadmium sorption capacity of Bacillus laterosporus, and the similar phenomenon of rapid adsorption in initial phase followed by slow chemical sorption phase was observed.

During the present study, it was also observed that the $B$. cereus sys 1 cells could adsorb cadmium faster than copper. The adsorption order of the biosorbent for metal adsorbate may be related to the properties of the metal adsorbate like ionic radius and electronegativity. The ionic radius of $\mathrm{Cd}(\mathrm{II})$ is $0.98 \AA$, while that of $\mathrm{Cu}(\mathrm{II})$ is $0.69 \AA$. The smaller the ionic radius, the greater is tendency to be hydrolysed, leading to reduced biosorption of $\mathrm{Cu}(\mathrm{II})$, and the electronegativity of $\mathrm{Cd}$ (II) (1.69 Pauling) is lower value than that of $\mathrm{Cu}$ (II) (1.9 Pauling). The sequence of selectivity followed the order of decreasing electronegativity and increasing ionic radius. A similar observation was reported on biosorption of $\mathrm{Cd}(\mathrm{II})$ and $\mathrm{Ni}(\mathrm{II})$ by $\mathrm{B}$. laterosporus by Kulkarni et al. [28].

\subsection{Surface characterization}

The SEM with EDX analysis confirmed the metal sorption on the cell surface. The cells grown in the presence and absence of oil were compared for their sorption efficiency. The comparative analysis of the surface elements is shown in Table 1. The study carried out on different Bacillus strains for metal biosorption showed similar results $[29,30]$.

\subsection{Adsorption isotherm}

Equilibrium adsorption isotherm studies were carried out with $10 \mathrm{mg} / \mathrm{ml}$ of biomass with copper concentration in the range of 25-1000 ppm and cadmium concentration in the rage of 10-250 ppm for $4 \mathrm{~h}$ (Figs. 6,7 ). The uptake for construction of isotherm was calculated using the equation $\left(C_{i}-C_{\text {eq }}\right) \times \frac{V}{M^{\prime}}$, where $C_{\mathrm{i}}$ is the initial metal concentration, $C_{\text {eq }}$ is the equilibrium metal concentration, $M$ is the mass of biomass in grams, and $V$ is the working volume of the metal solution in litre.

\subsubsection{Langmuir isotherm}

The Langmuir adsorption isotherm experimental data were plotted as $1 / q_{\mathrm{e}}$ on $Y$-axis versus $1 / C_{\text {eq }}$ on $X$-axis, and its constants $q_{\mathrm{m}}$ and $K_{L}$ were obtained by linear regression method as shown in Table 2 [20, 31-33]. The exponential data fit the Langmuir isotherm model. The maximum

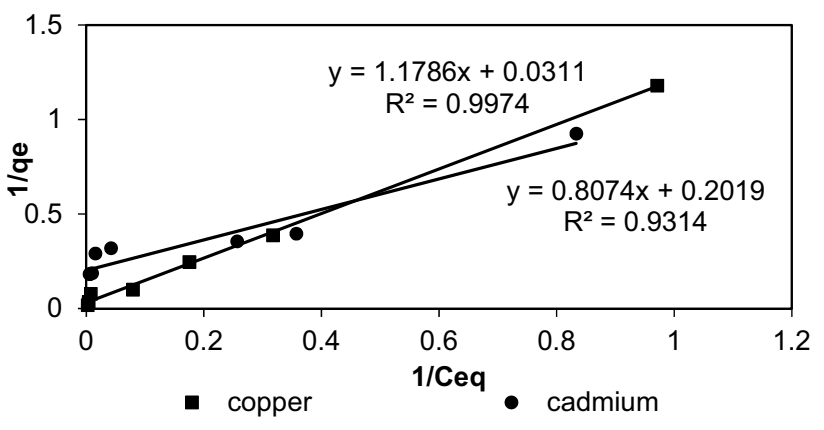

Fig. 6 Langmuir isotherm for copper and cadmium uptake by $B$. cereus cells

Table 1 Comparative analysis of weight $\%$ of elements present on cell surface

\begin{tabular}{|c|c|c|c|c|c|c|}
\hline Elements & $\begin{array}{l}\text { Cells } \\
\text { grown in } \\
\text { NB }\end{array}$ & $\begin{array}{l}\text { Cells grown } \\
\text { in NB + oil }\end{array}$ & $\begin{array}{l}\text { Cells grown in NB and } \\
\text { inoculated in Cu (100 } \\
\text { ppm) }\end{array}$ & $\begin{array}{l}\text { Cells grown in NB+oil } \\
\text { and inoculated in } \mathrm{Cu} \\
(100 \mathrm{ppm})\end{array}$ & $\begin{array}{l}\text { Cells grown in NB and } \\
\text { inoculated in Cd ( } 30 \\
\text { ppm) }\end{array}$ & $\begin{array}{l}\text { Cells grown in NB+oil } \\
\text { and inoculated in Cd } \\
(30 \mathrm{ppm})\end{array}$ \\
\hline C & 48.42 & 53.70 & 43.59 & 44.0 & 55.86 & 46.51 \\
\hline $\mathrm{N}$ & 6.55 & 5.97 & 9.52 & 8.98 & 0.00 & 0.00 \\
\hline $\mathrm{O}$ & 48.42 & 35.46 & 33.69 & 30.34 & 37.35 & 37.66 \\
\hline $\mathrm{Na}$ & 6.55 & 0.58 & 1.06 & 1.28 & 0.66 & 0.64 \\
\hline $\mathrm{Mg}$ & 40.84 & ND & ND & ND & ND & ND \\
\hline$P$ & 0.72 & 2.03 & 3.18 & 4.67 & 1.85 & 3.35 \\
\hline$S$ & 0.25 & 0.76 & 0.49 & 0.65 & 0.75 & 0.94 \\
\hline K & 1.44 & 1.18 & 0.90 & 1.91 & 0.90 & 1.17 \\
\hline $\mathrm{Ca}$ & 0.49 & 0.33 & ND & ND & ND & ND \\
\hline $\mathrm{Cl}$ & ND & ND & 0.28 & 0.61 & ND & 0.30 \\
\hline $\mathrm{Cu}$ & ND & ND & 7.29 & 7.55 & ND & ND \\
\hline $\mathrm{Cd}$ & ND & ND & ND & ND & 2.63 & 9.44 \\
\hline
\end{tabular}




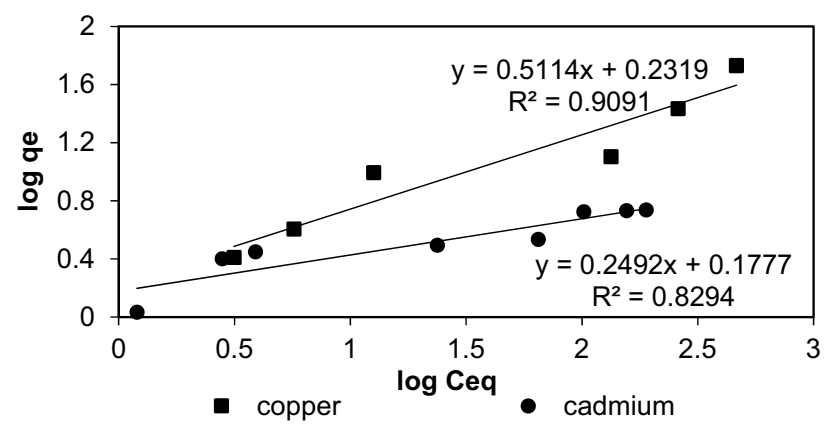

Fig. 7 Freundlich isotherm for copper and cadmium uptake by $B$. cereus cells

Table 2 Langmuir constants for copper and cadmium

\begin{tabular}{llll}
\hline Metal & $q_{\mathrm{m}}(\mathrm{mg} / \mathrm{g})$ & $K_{\mathrm{L}}(\mathrm{I} / \mathrm{mg})$ & $R_{\mathrm{L}}$ \\
\hline Copper & 225.07 & $3.76 \times 10^{-3}$ & 0.7049 \\
Cadmium & 34.67 & $3.57 \times 10^{-2}$ & 0.4660 \\
\hline
\end{tabular}

Table 3 Comparative data for copper and cadmium biosorption capacity of different microorganisms

\begin{tabular}{lll}
\hline Organism & $\begin{array}{l}\text { Biosorption } \\
\text { capacity }(\mathrm{mg} / \mathrm{g})\end{array}$ & References \\
\hline Copper & & \\
Bacillus cereus sys1 & 225 & Present study \\
Bacillus cereus $M_{16}^{1}$ & $104-714$ & {$[20]$} \\
Bacillus sp. (ATS-1) & 16.3 & {$[34]$} \\
Bacillus subtilis & 100 & {$[26]$} \\
Aspergillus niger & 23.62 & {$[19]$} \\
Micrococcus luteus & 33.33 & {$[35]$} \\
Pseudomonas aeruginosa & 70.4 & {$[30]$} \\
Kluyveromyces marxianus & 344.8 & {$[17]$} \\
Cadmium & & \\
Bacillus cereus sys1 & 34.67 & Present study \\
Bacillus cereus $M_{16}^{1}$ & 15.38 & {$[36]$} \\
Bacillus circulans strain EB1 & 26.5 & {$[37]$} \\
Bacillus laterosporus & 85.47 & {$[28]$} \\
Bacillus licheniformis & 142.7 & {$[38]$} \\
Aspergillus niger & 1.31 & {$[23]$} \\
Halomonas spp. & 12.023 & {$[16]$} \\
Pseudomonas aeruginosa & 58.5 & {$[30]$} \\
Ochrobactrum sp. GDOS & 83.33 & {$[22]$} \\
\hline
\end{tabular}

sorption was found to be $225 \mathrm{mg} / \mathrm{g}$ for copper and 34.67 $\mathrm{mg} / \mathrm{g}$ for cadmium. Comparative data for copper and cadmium biosorption capacity of different microorganisms are shown in Table 3.

The results of this study also support the assumptions of Langmuir model that the presence of a limited number
Table 4 Freundlich constants for copper and cadmium

\begin{tabular}{llll}
\hline Metal & $\left.K_{\mathrm{f}}(\mathrm{l} / \mathrm{mg})^{1 / n}\right)$ & $n$ & $1 / n$ \\
\hline Copper & 1.7051 & 1.7325 & 0.5114 \\
Cadmium & 1.5055 & 4.0128 & 0.2492 \\
\hline
\end{tabular}

of binding sites distributes over the biosorbent surface homogeneously, thus presenting the same affinity for biosorption of a single molecular layer [20]. The separation factor, $R_{L}$ obtained in the current study, is 0.7049 for copper and 0.4660 for cadmium, which indicates that the adsorption process is favourable using $B$. cereus sys 1 cereus.

\subsubsection{Freundlich isotherm}

The Freundlich adsorption isotherm was plotted as $\log q_{e}$ on $Y$-axis versus $\log C_{\text {eq }}$ on $X$-axis. The calculated Freundlich constants were found to be as given in Table 4 . The constant $K_{\mathrm{f}}$ is an approximate indicator of adsorption capacity, while $1 / n$ is a function of the strength of adsorption in the adsorption process. As the value of $1 / n$ reduces, heterogeneity increases. This study showed the $1 / n$ value as 0.5114 for copper and 0.2492 for cadmium which indicates a normal adsorption. A favourable sorption process is indicated by the value of ' $n$ ' lying between one and ten [39]. As the value of $n$ in the present study for both the metals was found to be higher than 1 and lesser than 10, it can be said that the adsorption intensity is favourable. Chatterjee and Ray [20] compared the copper sorption capacity of immobilized B. cereus $M_{16}^{1}$ cells. Their study showed that the $B$. cereus cells show normal adsorption with $1 / n$ being lesser than 1 as also observed in the present study. Liu et al. [26] reported their findings for immobilized Bacillus subtilis cells which confirmed that Bacillus spp. usually show normal and favourable sorption at higher concentration of copper.

\subsection{Kinetic models}

To determine the controlling mechanism of biosorption process, two kinetic models were used to interpret the experimental data using $100 \mathrm{ppm}$ copper concentration and $30 \mathrm{ppm}$ cadmium concentration.

\subsubsection{Lagergren's first-order kinetic model}

The correlation coefficient $\left(R^{2}\right)$ for the first-order kinetic plot of $100 \mathrm{ppm}$ concentration for copper was found to be 0.7. It suggests that the Lagergren's first-order plot does not adequately describe the adsorption having a low correlation coefficient (Fig. 8). Generally, the first-order kinetic 


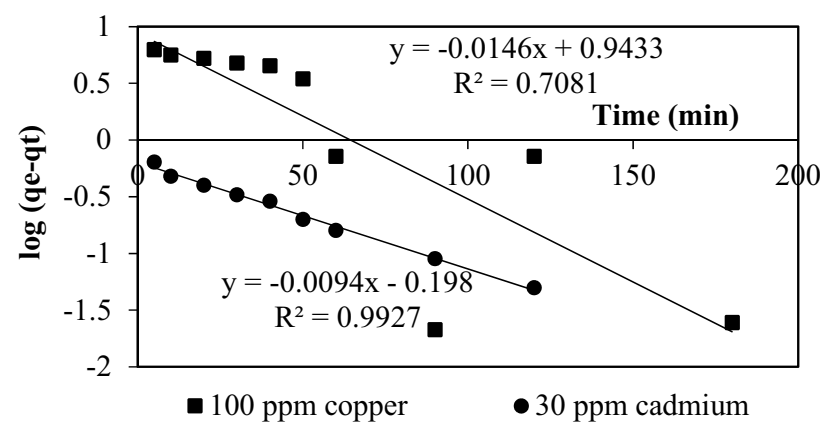

Fig. 8 Lagergren's first-order kinetic plot for copper and cadmium sorption

model is applicable for initial stage of the biosorption processes and does not fit well with the whole range of contact time [40]. In the current study, similar findings were observed with the lower correlation coefficient. Liu et al. [26] and Chatterjee and Ray [20] also have reported that the first-order kinetic model does not fit well for copper using Bacillus cells.

Unlike copper, first-order kinetic model fits well for all tested concentrations of cadmium with correlation coefficient values ranging from 0.98 to 0.99 . The same is shown in Fig. 8 for 30 ppm cadmium concentration. Similar results were observed by Kulkarni et al. [28] while studying the adsorption capacity of $B$. laterosporus.

\subsubsection{Ho's second-order kinetic model}

Second-order plots for all the concentrations of copper as well as cadmium were found to be linear with correlation coefficients higher than 0.9 , which indicates that the second-order kinetic model fits well with the experimental data. Figure 9 shows the second-order plot for 100 ppm copper and $30 \mathrm{ppm}$ cadmium. Table 5 represents the rate constants $\left(K_{1}, K_{2}\right)$ and adsorption capacity $\left(q_{e}\right)$ correlation coefficient for the same.

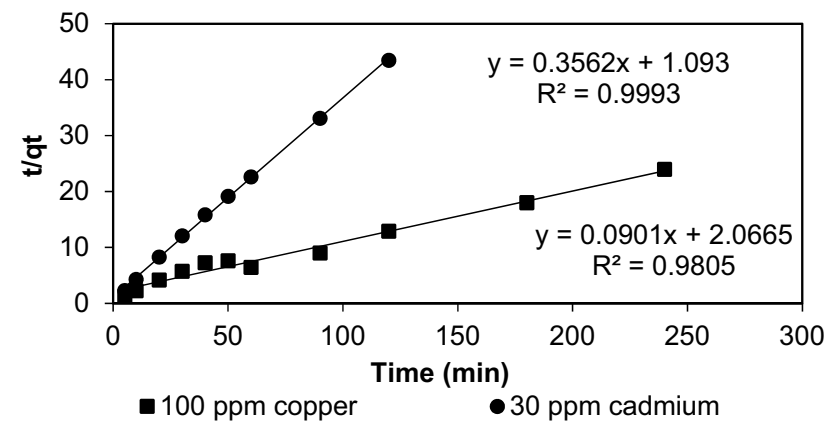

Fig. 9 Ho's second-order kinetic plot for copper and cadmium sorption
Table 5 Pseudo-first-order and second-order kinetics constants and correlation coefficients for copper (100 ppm) and cadmium (30 ppm)

\begin{tabular}{lllll}
\hline & Metal & $K(\mathrm{l} / \mathrm{min})$ & $q_{e}(\mathrm{mg} / \mathrm{g})$ & $R^{2}$ \\
\hline $\begin{array}{c}\text { Pseudo- } \\
\text { first-order }\end{array}$ & Copper & $K_{1}=3.3 \times 10^{-2}$ & 61.4362 & 0.7081 \\
$\begin{array}{c}\text { kinetics } \\
\begin{array}{c}\text { Pseudo-sec- } \\
\text { ond-order }\end{array}\end{array}$ & Copper & $K_{2}=3.9 \times 10^{-3}$ & 77.6914 & 0.9805 \\
kinetics & Cadmium & $K_{2}=1.2 \times 10^{-1}$ & 19.6518 & 0.9993 \\
\hline
\end{tabular}

The second-order kinetic model involves valency forces through sharing or exchange of electrons between adsorbent and adsorbate [41]. In chemisorption, the metal ions form a chemical bond and stick to the adsorbent surface. They usually tend to form a covalent bond and find sites that help them enhance the affinity towards absorbent surface by increasing their coordination number with the surface [42]. The pseudo-second-order kinetic analysis reveals that value of initial adsorption rates increases with increase in the initial metal ion concentration.

In the present study, it was observed that the metal adsorption rate increases from 100 to $1000 \mathrm{ppm}$ for copper and 10 to $30 \mathrm{ppm}$ for cadmium. The coefficient of correlation for pseudo-second-order kinetic model for different copper and cadmium concentrations was found to be 0.98 to 1.0. Both factors suggest that the biosorption of copper and cadmium ions followed the pseudo-second-order kinetic model, indicating that the rate-limiting step was a chemical biosorption process between metal ions and biosorbent through the exchange of electrons between the particles involved [43-46].

\section{Conclusion}

The present study evaluates possibility of using $B$. cereus sys 1 cells for biosorption of copper and cadmium. Effect of various parameters like $\mathrm{pH}$, cell concentration and metal concentration on biosorption was studied for process optimization. The comparison between different pre-treatments revealed that the adsorption capacity is dependent on the functional groups present on the surface and they might be affected due to the pre-treatments. Freundlich and Langmuir models as well as pseudo-secondorder plot exhibited good fit to $\mathrm{Cu}$ (II) and Cd(II) sorption which indicated a favourable and normal adsorption. The results from the study would contribute to understanding the potential of oil degrading strain of $B$. cereus sys 1 as a biosorbent. 


\section{Compliance with ethical standards}

Conflict of interest The authors declare that they have no conflict of interest.

\section{References}

1. Rajeswari TR, Namburu S (2014) Impact of heavy metals on environmental pollution. National seminar on impact of toxic metals, minerals and solvents leading to environmental pollution-2014 JCHPS Special Issue 3, pp 175-181

2. Perpetuo EA, Souza CB, Nascimento CAO (2011) Engineering bacteria for bioremediation. In: Carpi A (ed) Progress in molecular and environmental bioengineering-from analysis and modelling to technology applications. IntechOpen, Rijeka, pp 605-632

3. Patnaik R (2018) Impact of industrialization on environment and sustainable solutions-reflections from a south Indian region. IOP Conf Ser Earth Environ Sci 120:1-8. https://doi. org/10.1088/1755-1315/120/1/012016

4. Tchounwou PB, Yedjou CG, Patlolla AK, Sutton DJ (2012) Heavy metal toxicity and the environment. Exp Suppl 101:133-164. https://doi.org/10.1007/978-3-7643-8340-4_6

5. Brad HB (2004) Adsorption of metal ions on soils and soil constituents. J Colloid Interface Sci 277:1-18. https://doi.org/10.1016/j. jcis.2004.04.005

6. Davis TA, Volesky B, Vierra RHSF (2000) Sargassum seaweed as biosorbent for heavy metals. Water Res 34(17):4270-4278. https ://doi.org/10.1016/S0043-1354(00)00177-9

7. Abbas SH, Ismail IM, Mostafa TM, Sulaymon AH (2014) Biosorption of heavy metals: a review. J Chem Sci Technol 3(4):79-102

8. Bernhoft R (2013) Cadmium toxicity and treatment. Sci World J. https://doi.org/10.1155/2013/394652

9. Godt J, Scheidig F, Grosse-Siestrup C, Esche V, Brandenburg P, Reich A, Groneberg D (2006) The toxicity of cadmium and resulting hazards for human health. J Occup Med Toxicol 1(22):1-6. https://doi.org/10.1186/1745-6673-1-22

10. Bernard A (2008) Cadmium and its adverse effects on human health. Indian J Med Res 128:557-564

11. Gunatilake $S$ (2015) Methods of removing heavy metals from industrial wastewater. J Multidiscip Eng Sci Stud 1(1):12-18

12. Ahalya N, Ramachandra TV, Kanamadi RD (2003) Biosorption of heavy metals. Res J Chem Environ 7:71-79

13. Volesky B (1986) Biosorbent materials. Biotechnol Bioeng Symp $16: 121-126$

14. Gupte A, Sonawdekar S (2016) Production and characterization of exopolysaccharide produced by oil emulsifying bacteria. Int J Curr Microbiol Appl Sci 5(2):254-262. https://doi.org/10.20546/ ijcmas.2016.502.028

15. Arivalagan $P$, Kaliannan T, Singaraj D, Haridass V (2014) Removal of cadmium from aqueous solution by batch studies using Bacillus cereus. Ecol Eng 71:728-735

16. Rajesh N, Manasi Rajesh V, Kumar ASK (2014) Biosorption of cadmium using a novel bacterium isolated from an electronic industry effluent. Chem Eng J 235:176-185. https://doi. org/10.1016/j.cej.2013.09.016

17. Gupte A, Nair J (2013) Biosorption of copper by the yeast Kluyveromyces marxianus grown on whey. D Y Patil J Health Sci 1(1):35-38

18. González AG, Shirokova LS, Pokrovsky OS, Emnova EE, Martinez RE, Santana-Casiano JM, Gonzalez-Davila M, Pokrovski GS (2010) Adsorption of copper on Pseudomonas aureofaciens: protective role of surface exopolysaccharides. J Colloid Interface Sci 350:305-314. https://doi.org/10.1016/j.jcis.2010.06.020
19. Mukhopadhyay M, Noronha SB, Suraishkumar GK (2007) Kinetic modelling for the biosorption of copper by pretreated Aspergillus niger biomass. Bioresour Technol 98(9):1781-1787. https:// doi.org/10.1016/j.biortech.2006.06.025

20. Chatterjee A, Ray L (2008) Biosorption of Cu(II) by immobilized biomass of Bacillus cereus $M$ from aqueous solution. J Sci Ind Res 67:629-634

21. Aksu Z, Sag Y, Kutsal T (1992) The biosorption of copper by $C$. vulgaris and Z. ramigera. Environ Technol 13:579-586

22. Khadivinia E, Sharafi H, Hadi F (2014) Cadmium biosorption by a glyphosate-degrading bacterium, a novel biosorbent isolated from pesticide-contaminated agricultural soils. J Ind Eng Chem. https://doi.org/10.1016/j.jiec.2014.01.037

23. Kapoor A, Viraraghavan A (1998) Biosorption of heavy metals on Aspergillus Niger: effect of pre-treatment. Bioresour Technol 63:109. https://doi.org/10.1016/S0960-8524(97)00118-1

24. Merandi R (2011) Bioextraction of $\mathrm{Cu}(\mathrm{II})$ ions from acid mine drainage by Bacillus thuringiensis. Int J Biol Eng 1(1):11-17. https ://doi.org/10.5923/j.ijbe.20110101.03

25. Rajendran R, Jamaldheen S, Krishnamurthy M (2013) Biosorption of $\mathrm{Cu}(\mathrm{II})$ ions by indigenous copper-resistant bacteria isolated from polluted coastal environment. Toxicol Environ Chem 95:590-604. https://doi.org/10.1080/02772248.2013.801979

26. Liu YG, Liao T, He ZB, Li TT, Wang H, Hu XJ, Guo YM, He Y (2013) Biosorption of copper(II) from aqueous solution by Bacillus subtilis cells immobilized into chitosan beads. T Nonferr Metal Soc China 23:1804-1814. https://doi.org/10.1016/S1003 $-6326(13) 62664-3$

27. Babarinde NA, Oyesiku OO, Dairo OF (2007) Isotherm and thermodynamic studies of the biosorption of copper(II) ions by Erythrodontium barteri. Int J Phys Sci 2(11):300-304

28. Kulkarni RM, Shetty VK, Shrinikethan G (2013) Cadmium(II) and nickel(II) biosorption by Bacillus laterosporus (MTCC 1628). J Taiwan Inst Chem Eng. https://doi.org/10.1016/j.jtice.2013.11.006

29. Syed S, Chinthala P (2015) Heavy metal detoxification by different Bacillus species isolated from solar salterns. Scientifica 2015:319760. https://doi.org/10.1155/2015/319760

30. Zolgharnein H, Karami K, Asadi MM, Sohrab D (2010) Investigation of heavy metals biosorption on Pseudomonas aeruginosa strain MCCB 102 isolated from the Persian Gulf. Asian J Biotechnol 2(2):99-109. https://doi.org/10.3923/ajbkr.2010.99.109

31. Dada AO, Olalekan AP, Olatunya AM, Dada O (2012) Langmuir, Freundlich, Temkin and Dubinin-Radushkevich isotherms studies of equilibrium sorption of $\mathrm{Zn}^{2+}$ unto phosphoric acid modified rice husk. J Appl Chem 3(1):38-45. https://doi. org/10.9790/5736-0313845

32. Hameed BH, Foo KY (2010) Insights into the modelling of adsorption isotherm systems. Chem Eng J 156:2-10. https:// doi.org/10.1016/j.cej.2009.09.013

33. Hameed BH, Mahmoud DK (2008) Equilibrium modelling and kinetic studies on the adsorption of basic dye by a lowcost adsorbent: coconut (Cocos nucifera) bunch waste. J Hazard Mater 158(1):65-72. https://doi.org/10.1016/j.jhazm at.2008.01.034

34. Tunali S, Çabuk A, Akar T (2006) Removal of lead and copper ions from aqueous solutions by bacterial strain isolated from soil. Chem Eng J 115:203-211. https://doi.org/10.1016/j. cej.2005.09.023

35. Nakajima A, Yasuda M, Yokoyama H, Ohya-Nishiguchi H, Kamada H (2001) Copper biosorption by chemically treated Micrococcus luteus cells. World J Microbiol Biotechnol 17:343-347. https:// doi.org/10.1023/A:1016638230043

36. Ray L, Ganguly A, Guha AK (2011) Adsorption behaviour of cadmium by Bacillus cereus $M_{16}^{1}$ some physical and biochemical studies. Chem Speciat Bioavailab 23(3):175-182. https://doi. org/10.3184/095422911X13103800616341 
37. Yilmaz El, Ensari NY (2005) Cadmium biosorption by Bacillus circulans strain EB1. World J Microbiol Biotechnol 21:777-779. https://doi.org/10.1007/s11274-004-7258-y

38. Zouboulis Al, Loukidou MX, Matis KA (2004) Biosorption of toxic metals from aqueous solutions by bacteria strains isolated from metal-polluted soils. Process Biochem 39:909-916. https://doi. org/10.1016/S0032-9592(03)00200-0

39. Kumar U, Bandyopadhyay M (2006) Sorption of cadmium from aqueous solution using pre-treated rice husk. Bioresour Technol 97:104-109. https://doi.org/10.1016/S1003-6326(13)62664-3

40. Chatterjee S, Woo SH (2009) The removal of nitrate from aqueous solutions by chitosan hydrogel beads. J Hazard Mater 164:1012-1018. https://doi.org/10.1016/j.jhazmat.2008.09.001

41. Sağ Y, Aktay $Y(2002)$ Kinetic studies on sorption of $\mathrm{Cr}(\mathrm{VI})$ and $\mathrm{Cu}(\mathrm{II})$ ions by chitin, chitosan and Rhizopus arrhizus. Biochem Eng J 12(2):143-153. https://doi.org/10.1016/S1369 -703X(02)00068-2

42. Atkins PW (1995) Physical chemistry, 5th edn. Oxford University Press, Oxford
43. Wong KK, Lee CK, Low KS, Haron MJ (2003) Removal of Cu(II) and $\mathrm{Pb}$ (II) by tartaric acid modified rice husk from aqueous solutions. Chemosphere 50:23-28. https://doi.org/10.1016/S0045 -6535(02)00598-2

44. Dundar M, Nuhoglu C, Nuhoglu Y (2007) Adsorption of Cu(II) ions onto natural trembling poplar forest. J Hazard Mater 151(1):86-95. https://doi.org/10.1016/j.jhazmat.2007.05.055

45. Ho YS, McKay G (2000) The kinetics of sorption of divalent metal ions onto sphagnum moss peat. Water Res 34:735. https://doi. org/10.1016/S0043-1354(99)00232-8

46. Ho YS, McKay G (1999) Pseudo-second order model for sorption processes. Process Biochem 34(5):451

Publisher's Note Springer Nature remains neutral with regard to jurisdictional claims in published maps and institutional affiliations. 